\title{
Buddhist Priyatti Education Systems in Myanmar
}

\author{
Khemacara, Kumar Gautam Anand, Gurmet Dorjey
}

\begin{abstract}
As regards Buddhist Priyatti education system in Myanmar, since the 17th century, the PäliPathamapyan exam have always been conducted by the government and consequently been known as government examinations. Also considered are various formal examination boards and their curricula, such as the Sakyasīha, Cetiyangana, ant the Sāmanekyaw introduced by non-governmental Buddhist organizations during the 19th century; the stat eDhammācariya examinations, introduced by the government in 1946, and the first Tipitaka selection examination provided in 1948. Now a day, not only developed government Priyatti education systems, but also developed non-government Priyatti education and Buddhist University in Myanmar.
\end{abstract}

Theaim of this paper will approach four stapeses of study; the first one is that how to learn and way of life of monks and novices in Myanmar Priyatti monasteries; the second will be explorationthe government Priyatti education systems; the third will mentionnon-government educations; and the last onewill discover the condition of Priyatti Buddhist University in modern Myanmar and record the attitude of monastic communities by doing questionnaires survey.”

Keywords : Pathamabyan, Dhammācariya, Nikāya, Tipitakdhara selections, Sakyasiha, Samanekyaw, PriyattiBuddhist Universities.

\section{INTRODUCTION}

The duties of monkshood consist of Pariyatti and Patipatti. Pariyatti contains learning and teaching the Dhamma, while Patipatti is approaching the practice in accordance with the Dhamma. Patipatti involves practicing the Dhamma. It is about meditation which is of mainly two kinds - Samatha meditation and Vipassanā meditation. Samatha meditation is the practice mainly to develop one's concentration which can calm down the turmoil of the mental defilements (Kilesā). This kind of meditation can produce the results of Jhāna that are high levels of concentration. Vipassanā meditation is the practice mainly to develop understanding about the Dhamma. It is usually translated as insight meditation. The meditator learns to observe his body and mind objectively. This way, he sees the true nature of body and mind and this knowledge finally leads to the realization of the truths. (Suttanipāta Ațthakathā, Vol-1, p, 193)

Revised Manuscript Received on July 22, 2019.

Khemacara, Research Scholar, Sharda University, Noida (Uttar Pradesh), India.

Dr. Kumar Gautam Anand, Assistant Professor, Sharda University, Noida (Uttar Pradesh), India.

Dr. Gurmet Dorjey, Assistant Professor, Gautam Buddha University, Noida, (Uttar Pradesh), India.

In pāli texts, the meaningful of Dhura can be reasonably translated as "duty" or "obligation". There are some monks who work for Pariyattidhura while there are some others who practice meditation. There are also some monks who teach or learn the Dhamma while they are practicing meditation. In Myanmar, the young monks and novices move from place to place as long as they are still learning as try on Priyattidhura. When they become teachers, they usually live at one monastery where they teach their students. Usually, Pariyattimonasteries exist in urban areas.

\section{Priyattimonasteries entrances}

Most monks and novices at Pariyatti monasteries are originally from villages. They started their Pariyatti education in village monasteries and when they are ready for the higher studies, they go to the urban Pariyatti monasteries.In Myanmar, the administration procedure at Pariyatti monasteries varies. Some monasteries have strict regulations while others are more flexible. The admission procedure at the Pariyatti monasteries in ancient time and at present time is almost the same. Most monasteries give the admission to new students every year before Vassavasa-the rainy retreat. Usually, village monk teachers make the request to the chief monk of the urban Pariyatti monastery. Village teachers have to teach their students basic lessons such as reading, writing, etc. Young children in villages, about at the age of ten to twelve, usually are sent to the village monasteries where they start learning basic lessons. As mentioned above, there are some parents who sent their children to primary schools. If a child goes to primary school first and then only is sent to the monastery, he is about ten or eleven years old at that time. In this case, when he is admitted at the village monastery, he has already had the reading and writing and mathematics skills. At the village monastery, he starts his basic Pāli lessons such as grammar and some discourses in Pāli. The teachers usually teach their students for two or three years before they send them to Pariyatti monasteries in towns and cities. Therefore, the average age of the students admitted in the Pariyatti monasteries is between 11 and 15 . There are a few exceptional cases where young monks are also admitted at the Pariyatti monasteries. Sometimes, young men who have completed university graduation are attracted by the teaching and decided to become monks. 
They are mostly welcome at Pariyatti monasteries since they have strong basic for learning. Usually, they learn faster than the younger ones from villages.

New students usually bring their requisites with them. They bring a trunk where they keep their personal belongings. They bring a mat, a pillow, a blanket, a mosquito net, some robes, mugs, a toothbrush, toothpaste, soap, a towel, and some books and notebooks, etc. When they come to the Pariyatti monasteries, their parents and village teachers come with them since they want to show their respect and seriousness about the young students. Young students also must have a bowl which they use when they go for alms-round to the devotee local areas.

There is no entrance test for the admission. However, the teachers at the Pariyatti monasteries observe the new student's appearance and behaviors. They can see and judge the student's potential and attitude just by seeing them making movements and talking. However, there is usually a good relation between the teachers at the Pariyatti monasteries in towns and those from villages. This relation is all that require for the admittance of the new students.

In some Pariyatti monasteries, the new students have to find approval from some monks at the monasteries. The chief of the Pariyatti monastery give the new student the provisional admission. But the admission is confirmed only when the student gets the approval from one of the teachers and one of the students who are the residents of the monastery. This approval has more meaning in it. Those who provide the approval for the new students are responsible for the behavior of the latter. If the student who they give their approval misbehaves, they have to share half of the punishment that is given to the new student. For example, if the new student sneaks out of the monastery at night and he is to clean the water 20 plants in the monastery yard as the punishment, they also have to water 10 plants each. So, they must watch the student who they give approval, and they have to warn him accordingly. However, it is not usually difficult to find someone who is willing to take such responsibility since they had to go through the same procedure when they themselves are new comers. This procedure becomes so accustomed to the resident monks and they don't feel heavy for this responsibility. And the punishments are just to work for the monastery: such as cleaning the yard, watering the plants, changing the flowers in the shrine room or cutting firewood, etc. Everyone is happy to do such tasks even at normal time since they know they are doing wholesome works anyway.

\section{ACCOMmOdation in PARIYATtimonasteries}

When the student gets the admission, he is given a place to live. There are usually quite a few buildings at every Pariyatti monasteries. Some big Pariyatti monasteries have big buildings that can be two to three stories. There is a teacher who lives at that building and he is the one who is fully responsible for the students at his building.

The monastery like New Ma Soe YeinPriyattiMonastery in
Mandalay is quite big. But it has too many students who want to live and learn Pariyatti there for the monastery has a good reputation for its Pariyatti lessons. Sometimes New Ma Soe Yein Monastery accommodates over three thousand monks. The monks only get a three or four feet wide space where they eat, sleep and study the lessons. In some buildings, there can be over one hundred monks. Sometimes, new students can't get the accommodation there although they are admitted to live at the monastery. They have to live under trees and wait for the time when someone leaves the monastery for another place. If it is raining, they just sit inside the buildings or share a space with their friends.

Another monastery to compare with New Ma Soe Yein monastery is Shwe Hin Tha monastery in Sagaing. The monastery campus is about sixteen acres wide and there are more than twenty buildings. And the monastery accommodates just a little more than a hundred monks and novices. The monastery has a lot of space for each student. Some senior monks even have their own room where they can have privacy for their studies and stays. There are some two storey buildings at this monastery where only two or three monks dwell. It means that Shwe Hin Tha monastery has more buildings than the average requirement for monks.

In many monasteries, teachers have the entire floor if the building is two or three storey. The space is used for lectures and for public reception. Students from different buildings, sometimes from different monasteries come to a particular teacher for lessons. Teachers usually have at least three lectures every day and they have their day-off four days a month on the Sabbath Days.

Daily routine in Prityattimonasteries

PriyattiMonasteries start their day at 4:00 or 4:30 o'clock in the morning. They have a way to give a wake-up call to the students. Many monasteries use wooden drums to call for the attentions of all the resident monks and novices. Some monasteries strike the drum twenty-four times for the wakeup calls. The number twenty-four represents twenty-four conditions taught by the Buddha in Pațhāna, one of the texts of Abhidhamma. This number is probably used since it is quite enough to wake the resident monks up. Everyone gets up, keeps their beds, washes their face and gather at the shrine hall for the morning-prayer which, in Buddhist term, is paying homage to the Triple Gems - the Buddha, the Dhamma, and the Samgha. They chant Paritta that is a collection of some selected discourses and have some time to meditate. The type of meditation practice in early morning is usually Mettābhāvanā, loving-kindness meditation. The monks make good wishes for all beings. They make special good wishes for the people around the city to who they are going to see for the day.

Breakfast is served at dawn. In ancient time, when there was no clock, the color of the sky in the east shows the time. When the sky in the east turns red, before the sun rises, monks have breakfast. At some monasteries, there are laypeople who cook breakfasts for the monks. In most monasteries, novices take this responsibility. A typical breakfast consists of rice that the monks eat 
with beans and vegetable soup or fish-paste. At some monasteries, monks eat meals in their bowls. and at some others, they use plates. It depends on the numbers of the monks. At the monasteries that accommodate many monks prefer to use bowls for the monks can clean their bowls themselves. In small monasteries, they use plates for they don't need many plates and the washing-up is quite easy.

Sometimes, people come to offer monks meals - breakfast and lunch. When they offer breakfast, they stay at the monastery and cook the food. There are buildings for guests. There are some monasteries like New Ma Soe Yein monastery where it is quite a big work to offer meals to the resident monks. There the monks eat their breakfast when they come back from alms-round.

Just after breakfast time, the monks usually go for alms-round. At some education monasteries, monks go alms-round in groups. The most senior monk in a group leads the other monks who walk behind him in a queue. They go around some parts of the city along the usual route, stopping when they see people are waiting for them with some food to offer. At Shwe Hin Tha Monastery in Sagaing, three groups of monks go to different parts of the city. Each group has about twenty-five to thirty monks. They mostly get rice. They don't usually get much curry for there are many monks in Saging. People can't afford to offer curry for the monks every day. However, the monastery has some deposit money in the bank. The interest from the saving is used to cook curry for the monks at the monastery. People occasionally add their donations to the saving account so that monks may not need to worry about the food or some other necessities at the monastery. There are also people who come to the monastery on special days for them and offer meals. They make donations at the monasteries on the day when parents send their sons to get monks' ordination, on their birthdays, anniversaries, or the day when their parents pass-away.

When they come back from alms-round, they may have some time to take a rest and prepare for the lessons. Lessons usually start at nine o'clock. Lessons are one hour long. The time for the lessons is announced by the sound of wooden drums. When the students heard the sound, they go to the place where the lessons will be conducted. At monasteries in Myanmar, lessons are given at the buildings where teacher monks dwell. There aren't any separate buildings for lessons. The teachers' places serve as the classrooms. The students carry the texts and notebooks they need for the specific lesson. They approach the teachers respectfully. They sit on the floor before the teacher who sits on a chair. Some teachers use blackboards or whiteboards. For some lessons, written explanations are not necessary.

After the lessons, they have self-study hour until ten o'clock. At some monasteries, students study at their place. They may sometimes sit under the trees around the building they live. There are also some monasteries where student gather at a big hall to study. A senior monk or a teacher watches them while they are studying.

From ten to half past ten, monks take a bath, wash their clothes and shave their head. Most of Novices and Monks shave their heads on Sabbath days that fall on the eighth day of the new month, the full moon day, the eighth day after the full moon day and the moonless day. At some monasteries, monks shave their heads on the eve of the Sabbath days. it is not necessary for the monks, according to the Vinaya rules, to sheave so regularly. But teachers consider that uniformity is preferable. So, at most monasteries, especially the monasteries that belong to Shwe Kyin Sect, all monks shave on the same day.

Lunch is at half past ten and monks are informed of the lunch time with the sound of a wooden drum. This is common at the monasteries where monks eat at the same place at the same time. There are some monasteries, where monks have their meals separately at their convenient time. In this case, the lunch time telling is not necessary. If monks have meals together, the monastery has a separate place. They may share the food they receive from alms-round or there are some laypeople prepare food for them. Junior monks and novices usually finish their meals before the teachers finish. In fact, the teachers wait until the students finish their meals. Breakfast and lunch tables are, for the teachers in administration of the monasteries, the meeting where they have discussions about the Dhamma or the monasteries.

After lunch, they have their private time to rest. Some monks take a nap from twelve o'clock till a quarter to one. Novices and young monks prefer to do something instead of taking a nap. However, they must be doing things quietly in order not to disturb the ones who are resting.

Afternoon lessons start at one o'clock and again at three o'clock. From two to three, students have their private study-hour. At four o'clock, monks finish day-time lessons and from four to five they study on their own.

From five to six, they do the monastery works such as cleaning the yard and the buildings, gardening, watering the plants, cutting fire wood, or attending to the teachers. Most education monasteries have big and clean campuses. Some monasteries are very green too. Monks do not usually cut down big trees especially the ones that have already been there before they establish a new monastery. Monks believe that there can be guardian deities of the trees and cutting the trees down mean destruction of their places. But there are some times when they need to build a new building for the monks. In this case, they request the guardian deities of the trees to offer the place for the development of Sāsanā and request the guardian deities of the four directions to give the tree deities new places to dwell. They believe that tree deities have to obey the guardian deities of the four directions.

At present, the focus will be on the life of the monks in Pariyatti monasteries inthe location of urban areas. From six to half past six, the monks in Pariyatti Monasteries have free time. However, they do not usually go out to the city. They remain at their monastery going for walks around the campus or visiting their friends at another building. 
At half past six, monks gather at the prayer hall and pay homage to the Triple Gems, chant Paritta, listen to the Dhamma talk, receive some admonition from the chief monk or one of the teachers, and meditate a few minutes. After prayer, they recite their lessons by heart for an hour and then they do their homework. Learning the Dhamma by heart has been the tradition which goes back up to the time of the Buddha.

There were many monks who memorized the Dhamma as taught by the Buddha. Venerable Ānanda was known to be the best one who had the best memory. He knew all the teachings of the Buddha by heart. The people of that time did not have a habit of learning things through texts.

They learnt everything by heart. And they taught their students orally and the latter learnt by heart. Monks recite the lessons at night before they go to bed for it was the best time for memorizing things. An average student can study five to ten or even more stanzas during day time. He will be checked by a teacher at the end of the day. He tries to recall the lessons he has learnt during the day at night. If he doesn't remember the lessons thoroughly, he has to polish it again next day. Adding to that he also has to learn more lessons by heart. This way, day after day, he accumulates more and more lines or stanzas in the texts in his memory. One day, in the future, he may even become a Tipițakadhara, a treasurer of the Tipițaka.

By the time, when Vassavāsa is over, students have enough knowledge in their memory to learn Abhidhamma night-lessons. Usually night-lessons begin in November. Night-lessons are the lessons on Abhidhamma and Pāli grammar subjects. Abhidhamma subjects include Tikamātikā, Dhātukathā, Yamaka, and Paț̣hāna lessons. During Vassavāsa, monks learn Abhidhammatthasangaha. They learn Abhidhamma in analytical methods. They have to learn some analytical points on Abhidhamma by heart. Night-lessons are conducted based on the knowledge that the monks have acquired through the Abhidhammatthasangaha lessons. The lessons are conducted in dark. Students do not bring any text books since their learning is entirely based on their memory. The teachers explain the methods, students try to follow the teachers' explanations, and they recites Abhidhamma teachings using the methods. After the lessons, some students study the subject in groups or some individually.

All monks go to bed at ten o'clock. They usually have six hours at night and one hour during the day to sleep. Monks usually have their day-off four days a month, on Sabbath days. Some monasteries also give half day off on the eve of the Sabbath day. On their day-offs, monks shave their heads, wash their clothes, clean the monastery buildings and yard, and some young monks may go visit other monasteries or pagodas.

\section{Pariyattiexamination Systems}

The are many Buddhist examinations in Myanmar. It can be classified two types of Buddhistexaminations which are

governmental examination and private examination. The examinations are held yearly. Pāli Pathamabyan examinations, Dhammācariya examinations, Nikāya examinations and Tipitak selection examinations are organized by the Ministry of Religious Affairs know as governmental examinations.

PāliPathamabyan examinations have four levels. There are as follows:

1. AahkyapyuMula,

2. PathamNge,

3. PathamaLat, and

4. PathamaGyi.

They can be translated conveniently as beginner, Elementary, Intermediate and Advanced levels. There are some years, in the history of Pathamabyan examinations, when Beginner (AahkyapyuMula) level is added in the examinations.

The lessons are basic foundation of the three Tipitaka. Monks also have to learn Pāli writing and stanza-composition. Grammar subject is also studied for monks believe that without the knowledge of grammar, students will not be able to master the language and consequently they will not understand the true meaning of the teachings in Tipitaka. A grammatical text called Kaccāyana is recommended for the examinations. Another elaborate text related to it is Padarūpasiddhi. Further, for the foundation of Abhidhamma study, monks learn Abhidhammatthasangaha. This text is composed with nine chapters. For the elementary level, monks' study five chapters - Citta, Cetasika, Pakiṇnaka, Rūpa, and Samuccaya. The knowledge they have after learning these chapters enable them to follow Abhidhamma night-lessons. For the students of elementary level, Bhikkhupātimokkha is recommended. Bhikkhunipāțimokkha is learnt in intermediate level. These two texts are studied along with the commentaries on them - Kan̉khāvitaraṇiatțhakathā.

The subjects taught in night-lessons (Nyawar) from one subject in the examinations. Another subject is Myanmar literature. Myanmar translations of Jātaka stories are recommended for these levels. In Pathamalat level, Alaṇkāra and Chandodaya texts are also recommended. These texts help students to have the knowledge of Pạli composition. For Pathamalat and Pathamagyi, Abhidhānappadīpikā, a Pāḷi dictionary has to be learnt by heart. Students memorize the stanzas in the texts. Examinations are meant to test the students' memory and understanding of the recommended texts. (http://www.dra.gov.mm/?page_id=351accessed on 10/07/2019)

Dhammācariya examinations recommend three texts for the students. Pārājikaṇda-atṭhakathā is a commentary on the four Pārārjika rules of Vinaya. Sīlakkhandha Pāli and its atthhakathā represent SuttaPițaka. DhammasanghanīPāḷi, the first book of Abhidhamma, and Atṭhasālin̄i represent AbhidhammaPițaka. 
Each subject requires two papers questions that monks have to answer in two days continuously. Monks may either take all the three subjects in one year, or if they like, they can do two or even one separately. The subject they pass is recorded and when they have passed all three subjects, they are offered Sāsanadhaja-dhammācariya title and a degree. The name of this title suggests that the monks who have received it are the teachers of the Dhamma. They are considered qualify to teach the Dhamma to the students or to lay devotees. (http://www.dra.gov.mm accessed on 10/08/2019)

Some monks go further in their studies. There is another level of examination after Dhammācariya degree level. It is called Gon-htu-dan. It can be literally translated as "Distinction". This examination is divided into two sections Myanmar Gon-htu-dan and PāliGon-htu-dan. The other texts in Tipitaka are recommended for this examination. The students who take Myanmar Gon-htu-dan study the meaning and translation of the recommended texts and they can give their answers in Myanmar language. For Pāli Gon-htu-dan, monks have to give the answers in Pạli.

When they pass one of the examinations, they are offered Sāsanadhaja-sirīpavara-dhammācariya and Saāsanadhaji Dhamācariya-Pālipāragu tittles, degrees.

Further, in the word very famous and very difficult religious examinations is Tipitaka selection exams. The Buddha Sasananuggaha Committee headed by the wealthy Sir U Thwin submitted to the State to carry out the task of propagating Sasana successfully at Myanmar Country by celebrating convening of the Sixth Buddhist Synod with in Buddhist era 2500. Therefore, the State coordinated with other Theravada Buddhist countries for convening the Sixth Buddhist Synod. Because the other Theravada five countries asked the State whether there was the Three Pitaka reciter in Myanmar country, The Buddha Sasananuggaha Committee intended towards the appearance of Tipitaka reciter, Sasana-hero and Tipitakadhara selection committee was formed. Then, TipitakadharaTipitakakovidha examination was held starting from Myanmar Era 1310(1948).

To be degree holder of Tipitakadhara Tipitakakovidha, any one must pass five levels of reciting answer and five levels of idea by writing answer. The answerers must be only monks and novices who passed any one examination of Pathamagyi or Vinayavidu level or Third level of Thamanekyaw or Lecturer level of Cetiyangana and Sakyasiha.

The examination of reciting answer and ideology-examination of writing answer are held from last week of December to third week of January for 33 days. Every year at the second week of May, great auspicious celebration of offering honorable degree is held. Up to day, 13 Venerable Monks who got honorable Degree of Tipitakadhara, Tipitakakovidha and 8 venerable monks who got honorable Degree of Tipitakadhara appeared. 5-years after receiving TipitakadharaTipitakakovida Degree, State offers him TipitakadharaDhammabhandagarika

Degree.(http://www.dra.gov.mm accessed on 10/08/2019)
Another examinations is calledNikāya exams. To be skill in Nikaya, Dhammacariya examinations were invented, prescribed and held starting from Myanmar Era 1382 (1940). Not only three Commentaries of Parājika, Silakkhandha and DhammasanganiPāli and the Atthakatha of above Commentaries as three original Commentaries but also the remaining Pāli-Atthakatha Commentaries as Seven honored Commentaries Spreading 5 Nikāya were prescribed for the above lecturer-examinations. But the students endeavor to learn only the three based commentaries, and there are almost no students who want to endeavor to learn the honor commentaries. Because the persons who had passed the three original Commentaries of Dhammacariya lecturer level have ability to study and understand Pāli, Ațthakatha and Tika Commentaries, have to learn Nikāya Commentaries in order to spread out. Because at the time of decreasing faith and effort, there is almost no one who studied and learned Nikāya Commentaries, the latter became dead Commentaries. They arrived at the condition of the time when they were stored in the bureaus and cupboard only for show. Because the essence of Dhamma described in Nikāya commentaries were not known, the practice of Pariyatti meditations became decreased.

Therefore, the Supreme heads of presiding Monks invented and prescribed the selection examination of Tipitakadhara and held it starting in 1949. As reciting is based to answer these examinations, only bright Novice and Monks of great wisdom can answer above examinations and most of Persons and Monks cannot answer these.

The Venerable presiding Monks of State SaṃghamaMahāNāyaka Committee who have observed and considered that conditions, intending the Novice and Monks together with persons learn, understand and practice, the essence of the teaching of Buddha, agreed that written examination of 5-NikāyaPitakaPāli should be held so that all Novice and Monks together with persons can learn the Teachings of Buddha at the Fourth meeting attended by whole 47-members of State SaṃghaMahāNāyaka Committee. The Nikāya examinations were held starting from 1992 and promoted helding Mahavidua Examinations starting from 2000. Not only Monks, Novices, Nuns but also Persons who have been (12) years old at the first day of examination have the right to answer the examinations.

The following degrees and emblems are offered according to the respective Commentaries at Dhammācariya convocation, yearly:

\section{(a) Vidu Standard}

1. Group (1) Vinaya vidu

2. Group (2) Dhiga Nikāya vidu

3. Group (3) Majjhima Nikāya vidu

4. Group (4) Samyutta Nikāya vidu

5. Group (5) Anguttara Nikāya vidu

6. Group (6) Khuddaka Nikāya vidu (1)

7. Group (7) Khuddaka Nikāya vidu (2)

8. Group (8) Abhidhamma vidu (1) 
9. Group (9) Abhidhamama vidu (2)

(b) Maha-Vidu Standard

1. Group (1) Vinaya Maha Vidu

2. Group (2) Digha Nikāya Maha vidu

3. Group (3) Majjhima Nikāya Maha vidu

4. Group (4) Samyutta Nikāya Maha vidu

5. Group (5) Anguttara Nikāya Maha vidu

6. Group (6) Khuddaka Nikāya Maha vidu (1)

7. Group (7) Khuddaka Nikāya Maha vidu (2)

8. Group (8) Abhidhamma Mahā vidu (1)

9. Group (9) Abhidhamma Mahā vidu

(http://www.dra.gov.mm/?page_id=351accessed

15/08/2019)

\section{Non-governmentPariyatti Examinations}

Beside the governmental examinations, there are many priyatti examinations in Myanmar. Among then, the famous ones are described as follows:

1. Sakyasiha examination;

2. Cetiyangan examination; and

3. Samanekyaw examinations.

There are Pāḷi examinations organized by religious organizations. One of the most famous examinations is SakyasihaPariyatti Examination in Mandalay city.

The examination is a difficult one for most students to pass since the questions touch the most difficult aspect of the texts. Besides, there is an age limit. However, the difficulty in the examination is a challenge for some brilliant students. When the students pass this examination, they are offered the title "Abhivamsa of SakyasihaDhammācariya". This title represents a good reputation and great dignity among monk students. Young monks look up to the ones who have passed Sakyasiha Dhammācariya.

Further, another famous examination is called CetiyanganaPariyatti Examination in Yangon. This examination has almost the same good reputation as SakyasihaPariyatti Examination. Many monks try to pass these two examinations. The reason is that SakyasihaPariyatti Examination is held by the organization based in Mandalay, the largest city in Upper Myanmar and the other is held by the one based in Yangon, the former capital of Myanmar, in Lower Myanmar.

Further, the Sāmaṇekyaw Examinations are for Sāmaneras (Novices) under the age of twenty only. Like the Special Grades for Students and Teachers, the Sāmaṇekyaw Examination have oral test before one is allowed to sit for the written examinations. The syllabuses are as follows:

1. Grade One;

1. VinayaMahāvaggaPāli,

2. Añguttaranikāya: Ekakanipāta to Tikanipāta

3. DhammapadaPāli and Ațthakathā from Yamakavagga to Appamādavagga.

4. Kaccāyana's grammar: four chapters i.e.Sandhi, Nāma, Kāraka and Ākhyāta.

5. Abhidhammatthasangaha: the first three chapters i.e. Citta, Cetasika and Pakinnnakapariccheda.

2. Grade Two;

1. Culavagga and Parivāra
2. Anguttaranikāya: Ekakanipāta to Chakkanipāta.

3. DhammapadaPāli and Aṭ̣hakathā: Yamakavagga to Dạ̣ḍavagga.

4. Kaccāyana's grammar: the first six chapters i.e. Sandhi, Nāma, Kāraka, Samāsa, Taddhita and Ākhyāta.

5. Abhidhammatthasangaha: the first five chapters i.e. Citta, Cetasika, Pakiṇnaka, Vīthi and Vīthimutta.

\section{Grade Three;}

1. Pārājika and PācittiyaPāli.

2. Añguttaranikāya: all.

3. DhammapadaPāli and Aț̣hakathā: all.

4. Kaccāyana's grammar: all.

5. Abhidhammatthasañgaha: all.

Since its first Sāmaṇekyaw examination in 1950, the SakyasihaSāmaṇekyaw examinations is a first of all Sāmaṇekyaws and offering Sāmaṇekyaw degree. Nowadays number of Sāmaṇekyaw exams organization has increased held in Myanmar i.e. Yangon Sāmaṇekyaw, Pagu Sāmaṇekyaw, Towngyi Sāmaṇnekyaw etc.

\section{Priyatti Buddhist Universities}

Nowadays, most of Myanmar monk are learning the education systems of Buddhist University aftergetting Dhammācariya Degree or PāliPatthamabyan exams. Among theBuddhist University, the two State PariyattiSasana Universities and the International Theravada Buddhist Missionary University are under the government. And the others are non-government organizations. There are as follows:

1. International Theravada Buddhist Missionary University, Yangon;

2. State Pariyatti Sasana University, Yangon;

3. State Pariyatti Sasana University, Mandalay;

4. Sitagu International Buddhist Academy, Sagaing;

5. Sitagu Buddhist University, Yangon;

6. Sitagu Buddhist University, Mandalay;

7. Sitagu Buddhist University, Towngu;

8. Sitagu Buddhsit University, Kyunhla;

9. Shan State Buddhist University; Taunggyi;

10. DhammadutaBuddhist University, Bago;

11. Dhammaduta Chekinda University, Yangon;

12. University of Global Peace, Patheingyi, Mandalay;

13. Buddhist University, Yangon;

14. Buddhist University, Mandalay,

15. Mahāvihara Dhamma-Vinaya University;

16. Ramannyarattha Buddhist University, Mowlamyine; and

17. PantapwinttaungBuddhist University, Taikkyi, Yangon.(https://en.wikipedia.org/wiki/List_of_Buddhist_un iversities_and_colleges accessed on 13/09/2019)

In Myanmar, there are many famous Buddhist monasteries in Myanmar. Theravada Buddhist Scriptures could be learnt. Sitagu International Buddhist Academy at Sagaing, founded in 1994 by Sayadaw Ashin Nanissara. Unlike described earlier Universities, the International Theravada Buddhist Missionary University which will be inaugurated in Yangon on 9thDecember, 1998. It will be a significant institution not only in Myanmar but also in the whole 
world. It will be the place where international Buddhist scholars can learn bothscriptural Study (Pariyattidura) and (Meditation Practice (Patipattidura) at the same time. It distinguishes for being free tuition, free mission, free lodging and free health care to those foreign scholars.

\section{Data Analysis on Priyattieducation systems}

To analyze general ideas of the a hundred monks in Myanmar, I have set six questions regarding the monasticPriyattieducation systems. Of six questions related to opinion of Priyatti education, the first questions is that what do you think about monkhood and monasticPriyatti education. It has four options: (a) Good; (b) Excellent; (c) Bad; (d) Very bad.

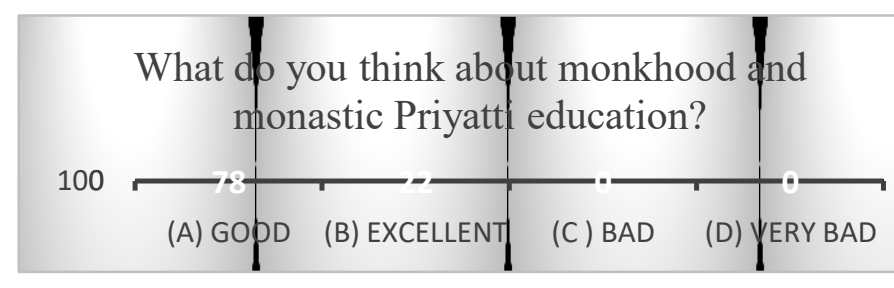

Inthis first question, $78 \%$ of monks give their reference onPriyatti education systems is "Good", and $22 \%$ give "Excellent".

The second question is that which is the most important Language for the priyatti educations.

It is asked five options:(a) Pāli; (b) Sanskrit (c) English (d) Local Language; and (e) Others.

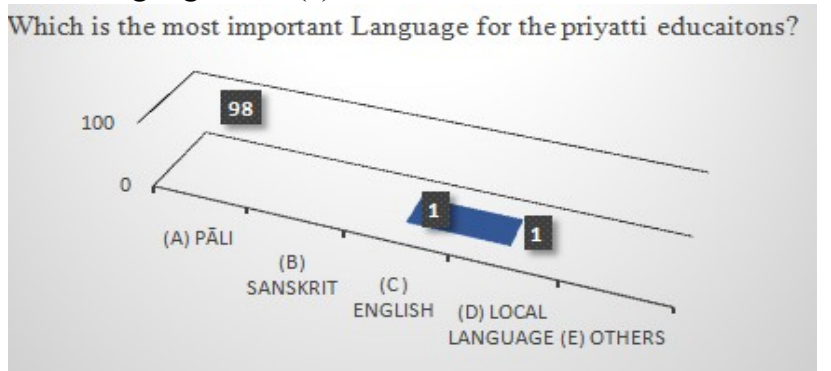

Regarding the question number two, 98\% of monk's responded that thePāli Language is important for monasticPriyatti educations, whereas recommended only $1 \%$ English and 1\%local Language.

The third question is relating to current Priyatti learning skills. It is asked that how do you rate on the current learning skills in monastic community. Here, four kinds of options are: (a) Good; (b) bad; (c) Appropriate; (d) Very good; and (e) Very bad.

Regarding the Priyatti learning skills, $76 \%$ of monks decide on "Good", $20 \%$ of monks accepted by "Appropriate" and $4 \%$ of say "Very good".

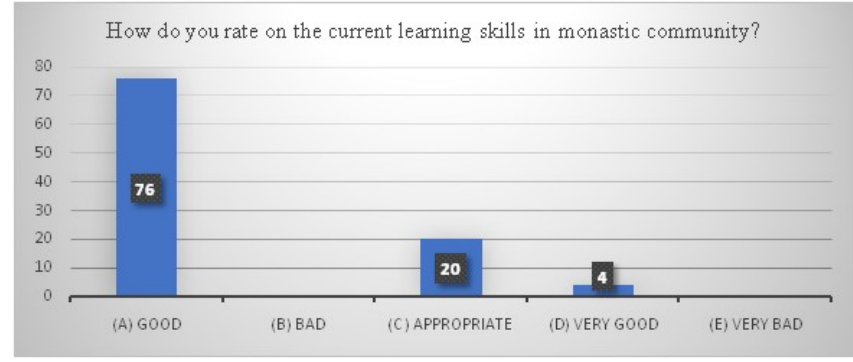

The fourth question isview onPriyatti education currently.The question is"rate the current Monastic Education system". And it has five selections: (a) Good; (b) Bad; (c) Acceptable; (d) Very good; and (e) Very good.

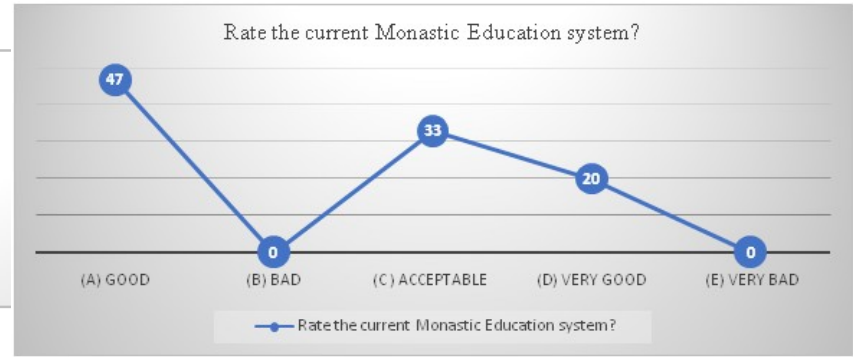

In this fourth question, $47 \%$ of monks answerthe condition of good, 33\% regard as acceptable, and 20\% rate that "very good".

The fifth question is related the purposes of monastic priyatti education. The question is "what are the purposes of your monastic education". There options are: (a) Learning; (b) Practicing; (c) Learning and practicing; (d) Maintaining; (e) Propagations; and (f) Others.

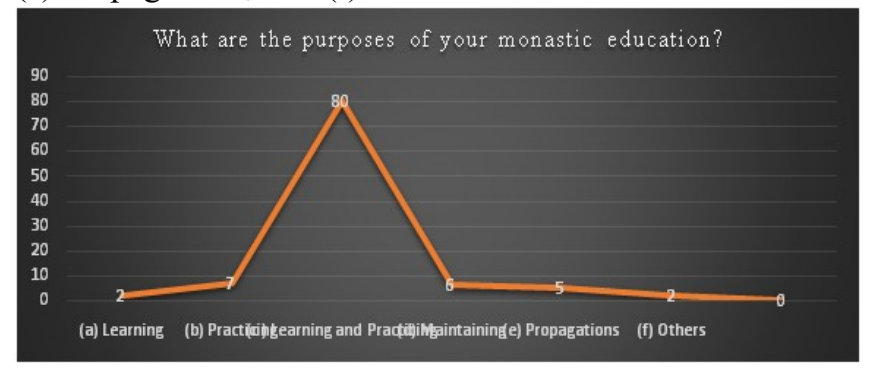

Regarding the fifth question, $80 \%$ of monk reply 'Learning and Practicing', whereas 7\% answer 'Practicing', $6 \%$ of them respond their opinion as maintaining, $5 \%$ fulfill for propagations, $2 \%$ give for Learning and $2 \%$ remarkthat'other'.

What are the challenges of monastic priyatti education system?

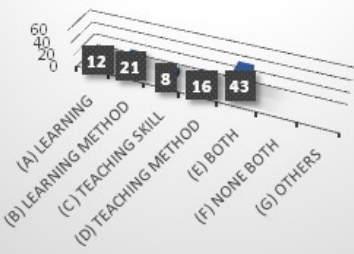

The last question is related to challenges of monastic Priyatti education. The question is "what are the challenges of monastic education system". It has seven options: (a) learning; (b) Learning method; (c) Teaching skill; (d) Teaching method; (e) Both; (f) None both; and (g) Others. 


\section{Buddhist Priyatti Education Systems in Myanmar}

Regardingthe last question, $12 \%$ of monk input 'Learning', 21\% select 'Learning method', 8\% decide on 'Teaching skill', 16\% say'Teaching method' and $43 \%$ record 'Both'.

\section{Government Priyatti examinaton systems in Myanmar}

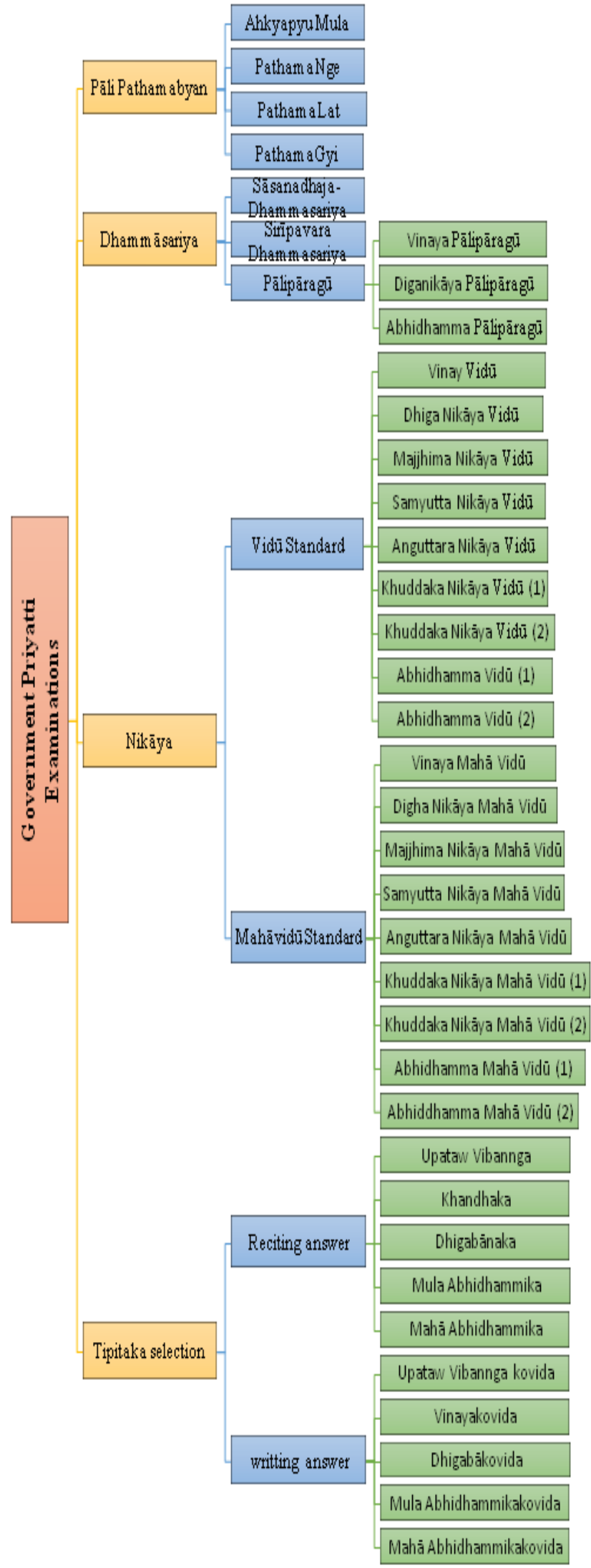

Non-Government Pariyatti Education in Myanmar

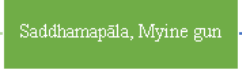

Sardhadam

(a)

Samanekyaw Greade- $1 / 2$

Sarthindam
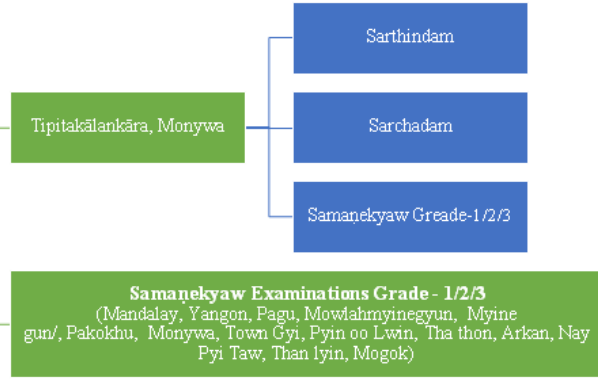

Priyatti Buddhist Universitres in Myanmar

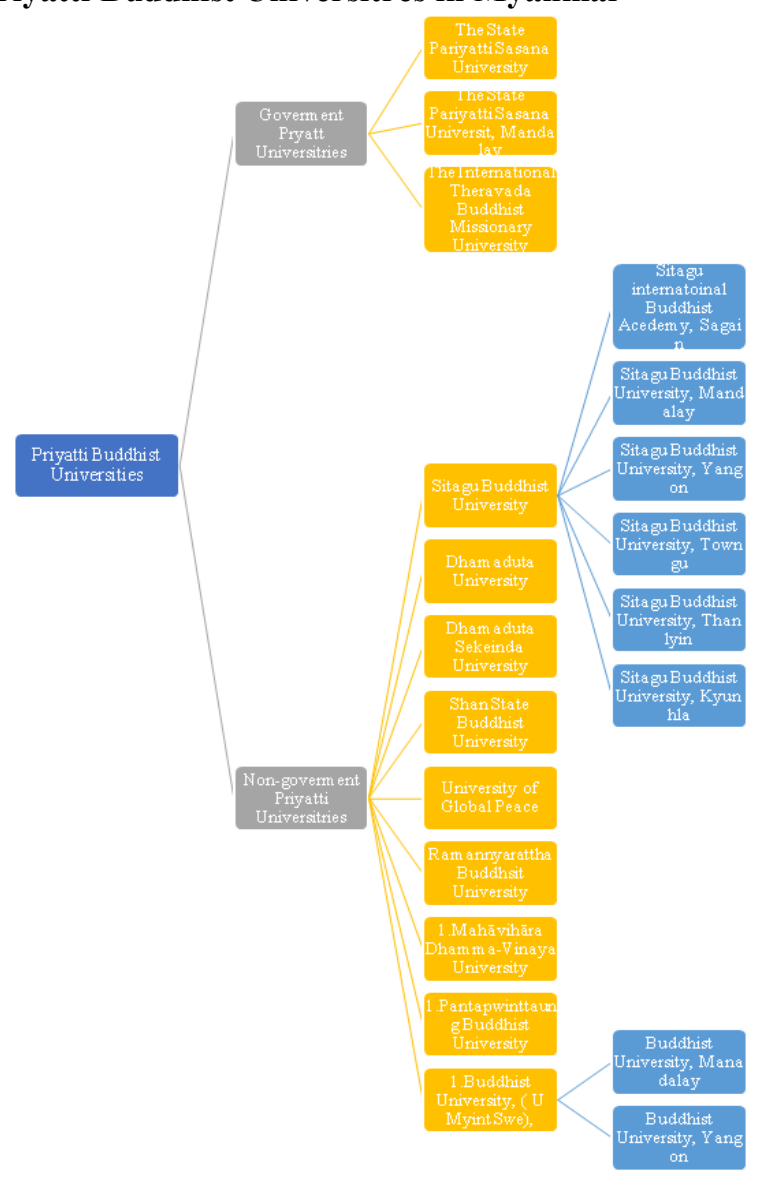

Government Priyatti educaton systems

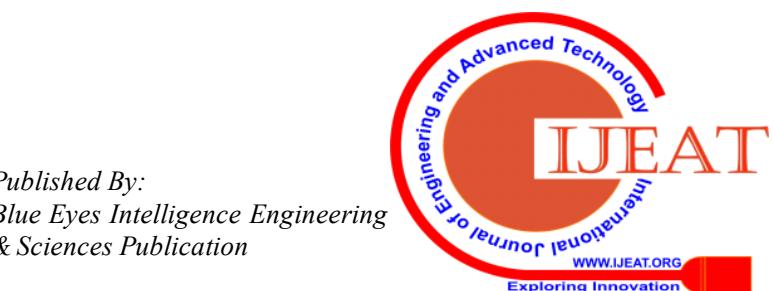




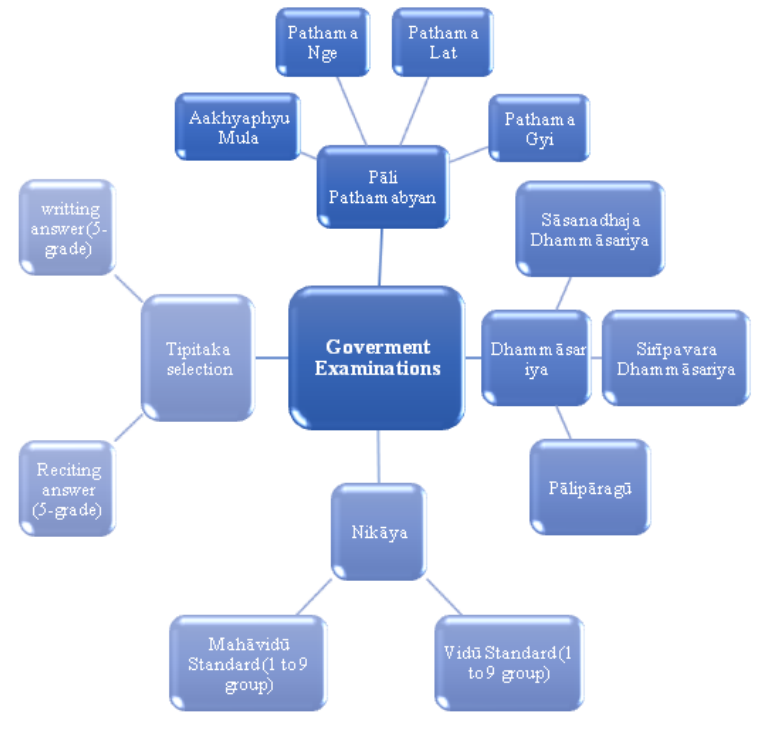

\section{Conclusions}

The communities of monastic of members- monks and novices are performing their obligation in daily life and way of life as a Ganthadhura- learning and teaching in Myanmar.The field presented it and the situation of BuddhistPriyatti education systems currently.

In conclusion, the government of union of Myanmar provides the state Priyatti examinations and confers the titles. The fundamental one -PāliPathambyan Examination - has four levels. To continue their Priyatti education, students may sit for the Dhammacariya examinations, testing their knowledge of Tipitaka and confer-ring them the title of Sasanadhaja Dhammācariya.There are also an Honorary Dhannacariya examination, which the title of Sasanadhaja Siripavara Dhammācariya and Pāli Pāragū .Whereas, the systems of Nikāya exams also the famous one in Myanmar whit their titles VinayVidu etc. For especially talented candidates, there are Tipitakadhara Examinations. If he passes all three examinations, he obtains the title of Tipitakadhara, Tipitakakovida or Tipitakadhara Dhammabandagarika. The successful candidates are held in highest respect in the country. There are two State Pariyatti Sasana Universities in Yangon and Mandalay, with both traditional and modern systems of teaching. Alongside them, there are also the International Theravada Buddhist Missionary University in Yangon, Sitagu International Buddhist Academy, Shan State Buddhist University; Taunggy, DhammadutaBuddhist University, Bago; Dhammaduta Chekinda University, Yangon etc.

The results from this studywill come to view that the daily routine of monks and novices inPriyattimonasteries, government and non-government Priyatti examinations systems, the summaries of Buddhist Priyatti Universities andtheattitude oncurrent BuddhistPriyatti education systems.

\section{REFERENCES}

[1] Buddhaghosa, Thera,Suttanipāta Atṭhakathā, Vol-1, (1984) Yangon: Department of Religious Affairs Press

[2] Buddhaghosa, Thera, Dhammapad Aț̣hakathā, Vol-1, (1984) Yangon: Department of Religious Affairs Press

[3] Buddhaghosa, Thera,TheraAțțhakathā, Vol-2, (1958) Yangon: Department of Religious Affairs Press

[4] http://www.dra.gov.mm/?page id=351

[5] https://en.wikipedia.org/wiki/List_of_Buddhist_universities_and_colleges

[6] https://en.wikipedia.org/wiki/International_Theravada_Buddhist_Mission ary_University

[7] https://en.wikipedia.org/wiki/State_Pariyatti_Sasana_University,_Manda lay 